\title{
Pengaruh Pemberian Probiotik Kering Berbasis Susu Sapi, Kacang Hijau, dan Kedelai terhadap Performa Ayam Broiler
}

\section{Effect of Dried Probiotics Based Cow's Milk, Mung Bean, and Soybean on Growth Performance Broiler Chicken}

\author{
C. Kumalasari ${ }^{1 *}$, I. Setiawan ${ }^{2}$, dan L. Adriani ${ }^{2}$ \\ ${ }^{1}$ Program Pascasarjana, Fakultas Peternakan, Universitas Padjadjaran, Bandung - Indonesia \\ ${ }^{2}$ Program Studi Ilmu Peternakan, Fakultas Peternakan, Universitas Padjadjaran, Bandung - Indonesia \\ *Corresponding E-mail: chitrakumalasari@gmail.com \\ (Diterima: 6 November 2019; Disetujui: 8 Januari 2020)
}

\begin{abstract}
ABSTRAK
Penelitian ini bertujuan mengetahui pengaruh pemberian probiotik kering terhadap performa pertumbuhan meliputi konsumsi ransum, pertambahan bobot badan, dan konversi ransum. Penelitian dilaksanakan pada 6 Agustus hingga 6 September 2019 di kandang Test Farm, Fakultas Peternakan, Universitas Padjadjaran. Metode penelitian menggunakan Rancangan Acak Lengkap dengan lima perlakuan dan empat kali ulangan. Perlakuan yang diberikan; P0: ransum basal, P1: ransum basal + probiotik kering A (susu sapi fermentasi 100\%), P2: ransum basal + probiotik kering B (susu sapi fermentasi $75 \%+$ susu kacang hijau fermentasi 25\%), P3: ransum basal + probiotik kering C (susu sapi fermentasi $75 \%+$ susu kedelai fermentasi 25\%), dan P4: ransum basal + probiotik kering D (susu sapi fermentasi $50 \%+$ susu kacang hijau fermentasi $25 \%+$ susu kedelai fermentasi $25 \%$ ). Setiap perlakuan diberikan sebanyak $2 \%$ dari total ransum. Probiotik kering mengandung empat bakteri asam laktat diantaranya Lactobacillus bulgaricus, Lactobacillus acidophilus, Streptococcus thermophilus, dan Bifidobacterium bifidum. Hasil analisis ragam menunjukkan konsumsi ransum dan konversi ransum tidak berbeda nyata $(P>0,05)$ namun adanya perbaikan, sedangkan pertambahan bobot badan menunjukkan perbedaan yang nyata $(P<0,05)$ meningkatkan, artinya penambahan probiotik kering mampu meningkatkan kecernaan dan efesiensi pencernaan. Kesimpulannya penggunaan probiotik kering mampu meningkatkan performa pertumbuhan.
\end{abstract}

Kata kunci: pertambahan bobot badan, probiotik kering, konsumsi ransum, konversi ransum

\section{ABSTRACT}

This study aimed to know the effect of administration of dried probiotics on growth performance including ration consumption, body weight gain, and feed conversion ratio. This research was conducted on 6 August to 6 September 2019 at the Test Farm, Animal Husbandry Faculty, Padjadjaran University. A total of 100 Day Old Chick Cobb broilers were randomly assigned to five treatments and four replications used Completely Randomized Design. The treatment included; P0: basal ration without dried probiotic, P1: basal rations + dried probiotic A (100\% fermented cow's milk), P2: basal rations + dried probiotic $B(75 \%$ fermented cow's milk + fermented mung bean milk), P3: basal rations + dried probiotic $C$ (75\% fermented cow's milk $+25 \%$ fermented soybean milk), and P4: basal ration + dried probiotic $D$ $(50 \%$ fermented cow's milk $+25 \%$ fermented mung bean milk $+25 \%$ fermented soybean milk). Each treatment was given as much as $2 \%$ dried probiotic of the total ration. Dried probiotics contain lactic acid bacteria including Lactobacillus bulgaricus, Lactobacillus acidophilus, Streptococcus thermophilus, and Bifidobacterium bifidum. The results of the analysis variance showed favorable body weight gain in dried probiotic group administration $(P<0.05)$. Feed intake and feed conversion ratio were an improvement but not significantly different $(P>0.05)$, indicatively showed improvement in digestibility and digestion efficiency. The conclusion is the administration of dried probiotics improved growth performance.

Keywords: body weight gain, dried probiotics, feed conversion ratio, feed intake 


\section{PENDAHULUAN}

Ayam broiler merupakan ternak unggas yang dipelihara dengan tujuan untuk produksi daging. Daging ayam broiler banyak dikonsumsi oleh masyarakat Indonesia karena harga relatif murah dan mudah didapatkan. Peningkatan konsumsi daging ayam broiler perlu di tunjang oleh managemen yang tepat selama pemeliharaan agar kualitas performa ayam yang dihasilkan tetap baik dan stabil.

Feed additive diperlukan untuk menunjang tujuan pemeliharaan ternak. Salah satu feed additive yang biasa digunakan adalah antibiotic growth promotor. Namun penggunaannya sudah dilarang karena dapat menimbulkan residu dalam daging. Alternatif antibiotik yang sudah banyak digunakan adalah probiotik. Probiotik merupakan mikroba hidup yang bila diberikan dalam jumlah cukup akan memberi manfaat kesehatan pada ternak yang mengonsumsinya (Hill et al., 2014).

Penggunaan probiotik cair pada ayam broiler kurang efektif karena mudah terkontaminasi silangdan penggunaannya tidak praktis, sedangkan probiotik dalam bentuk kering menjadi alternatif baru sehingga lebih tahan lama dan lebih mudah dalam penggunaan. Probiotik kering dalam penelitian ini mengandung bakteri asam laktat diantaranya Lactobacillus bulgaricus, Lactobacillus acidophilus, Streptococcus thermophilus, dan Bifidobacterium bifidum yang dalam fermentasinya menggunakan media susu sapi dengan penambahan susu kedelai dan kacang hijau sehingga kandungan bahan aktifnya menjadi lebih tinggikarena terdapat isoflavon dalam bentuk aglikon. Susu sapi mengandung laktosa yang dapat dimanfaatkan langsung sebagai sumber energi atau sumber karbon oleh bakteri asam laktat sedangkan susu kacang hijau dan kacang kedelai mengandung oligosakarida, sehingga dalam fermentasi susu kedelai dan kacang hijau perlu dicampurkan dengan susu sapi. Oligosakarida merupakan bahan energi untuk pertumbuhan BAL akan tetapi komponen dari oligosakarida itu sendiri tergolong karbohidrat yang kompleks sehingga harus diubah terlebih dahulu menjadi monosakarida (Triyono, 2010).

Probiotik kering berperan dalam saluran pencernaan mampu meningkatkan performa pertumbuhan ternak, yaitu konsumsi ransum, konversi ransum, pertambahan bobot badan yang optimal karena meningkatnya fungsi pencernaan dan daya cerna nutrien.Peran probiotik memungkinkan daya cerna dan daya serap nutrien meningkat dengan cara menekan bakteri patogen dalam saluran pencernaan sehingga mendukung perkembangan bakteri baik yang membantu penyerapan zat nutrien (Kompiang, 2002). Probiotik dapat mengubah pergerakan mucin dan populasi mikroba di dalam usus halus ayam, sehingga keberadaannya dapat meningkatkan fungsi dan kesehatan usus, memperbaiki komposisi mikroba pada sekum, serta meningkatkan penyerapan zat makanan (Mountzouris et al., 2010). Probiotik dapat meningkatkan aktivitas enzim sukrosa, laktosa, dan tripeptidase di usus halus. Pemberian probiotik dari periode awal memungkinkan meningkatkan keseimbangan mikroba usus (Adriani et al., 2019). Penelitian mengenai probiotik cair dengan kombinasi susu sapi dan susu kacang kedelai fermentasi terhadap performa pertumbuhan ayam broiler sudah banyak dilakukan. Namun penggunaan probiotik kering dengan kombinasi susu sapi, susu kacang hijau, dan susu kedelai fermentasi belum banyak dilakukan, sehingga penelitian ini sangat diperlukan untuk mengetahui pengaruh probiotik kering terhadap performa pertumbuhan.

\section{METODE}

\section{Ternak Percobaan}

Penelitian dilaksanakan di kandang semi-closed house Test Farm, Fakultas Peternakan, Universitas Padjadjaran. Ternak yang digunakan adalah ayam broiler dari umur satu hari (Day Old Chick/DOC) strain Cobb sebanyak 100 ekor tanpa pemisahan 
JPI Vol. 22 (1): 110-118

Tabel 1. Kandungan energi metabolis dan nutrien dalam bahan pakan penelitian

\begin{tabular}{lccccccccc}
\hline Bahan Pakan & $\begin{array}{c}\text { EM } \\
(\mathrm{Kkal} / \mathrm{kg})\end{array}$ & $\begin{array}{c}\text { PK } \\
(\%)\end{array}$ & $\begin{array}{c}\text { LK } \\
(\%)\end{array}$ & $\begin{array}{c}\text { SK } \\
(\%)\end{array}$ & $\begin{array}{c}\text { Ca } \\
(\%)\end{array}$ & $\begin{array}{c}\text { P } \\
(\%)\end{array}$ & $\begin{array}{c}\text { Lis. } \\
(\%)\end{array}$ & $\begin{array}{c}\text { Sis. } \\
(\%)\end{array}$ & $\begin{array}{c}\text { Met. } \\
(\%)\end{array}$ \\
\hline Jagung & 3.370 & 8,60 & 3,90 & 2,00 & 0,02 & 0,10 & 0,20 & 0,18 & 0,18 \\
Bungkil kedelai & 2.240 & 45,00 & 0,90 & 6,00 & 0,32 & 0,29 & 2,90 & 0,67 & 0,65 \\
Tepung ikan & 3.080 & 45,00 & 9,00 & 1,00 & 5,50 & 2,80 & 5,00 & 0,94 & 1,80 \\
Minyak Kelapa & 8.600 & 0 & 100,00 & 0 & 0 & 0 & 0 & 0 & 0 \\
Tepung tulang & 0 & 0 & 0 & 0 & 24,00 & 12,00 & 0 & 0 & 0 \\
L-Lisin & 0 & 95,80 & 0 & 0 & 0 & 0 & 78,50 & 0 & 0 \\
DL-Methionin & 0 & 58,00 & 0 & 0 & 0 & 0 & 0 & 0 & 99,00 \\
\hline
\end{tabular}

Sumber: Laboratorium Produksi Ternak Unggas Fakultas Peternakan Universitas Padjadjaran (2015)

Tabel 2. Kandungan energi metabolis dan nutrien pada ransum penelitian

\begin{tabular}{lc}
\hline Nutrien & Jumlah kandungan \\
\hline Energi Metabolis (kkal/kg) & 3.066 \\
Protein Kasar (\%) & 21,37 \\
Serat Kasar (\%) & 3,13 \\
Lemak Kasar (\%) & 0,50 \\
Lisin (\%) & 1,29 \\
Metionin (\%) & 0,54 \\
Metionin+sistin (\%) & 0,74 \\
Kalsium (\%) & 0,83 \\
Fospor (\%) & 0,42 \\
\hline
\end{tabular}

jenis kelamin dengan koefisien variasi bobot badan tidak lebih dari 10 persen. Ayam broiler diberi 5 perlakuan dan diulang sebanyak 4 kali sehingga setiap unit percobaan berisi 5 ekor. Kandang yang digunakan sebanyak 20 unit dengan ukuran masing-masing 1 x $0,5 \times 0,75 \mathrm{~m}$. Setiap ekor diberi wing tag pada sayap sebelah kanan untuk memudahkan pengamatan dan pengumpulan data. Manajemen pemeliharaan ayam broiler menggunakan lampu 75 watt dengan rataan suhu $25-28^{\circ} \mathrm{C}$. Ransum yang diberikan pada fase starter dan fase grower sama, yaitu ransum basal yang disusun sendiri (Tabel 1) dengan kandungan energi metabolis $3.066 \mathrm{kkal} / \mathrm{kg}$ dan protein 21,37\% (Tabel 2). Pemberian ransum diberikan ad libitum pada pagi dan sore hari. Peralatan yang digunakan diantaranya lampu 75 watt, wing tag, round feeder, round waterer, timbangan digital kapasitas $5 \mathrm{~kg}$ dan $10 \mathrm{~kg}$ dengan tingkat ketelitian masing-masing $0,1 \mathrm{~g}$ dan $1 \mathrm{~g}$, karung untuk penyimpanan ransum, higromometer, dan peralatan kebersihan.

\section{Probiotik Kering}

Probiotik kering berasal dari fermentasi susu sapi, susu kacang hijau, dan susu kedelai yang formulasinya disesuaikan dengan perlakuan. Ketiga jenis susu tersebut diinkubasi dengan empat bakteri asam laktat, diantaranya Lactobacillus bulgaricus, Lactobacillus acidophilus, Streptococcus thermophilus, dan Bifidobacterium bifidum. Proses pengeringan probiotik disalut dengan maltodekstrin DE 10-12 (food grade) sebanyak $5 \%$ sebagai nutrisi bagi bakteri dan bertujuan menjaga bakteri asam laktat tetap hidup. Pengeringan dilakukan pada oven dengan suhu $40^{\circ} \mathrm{C}$ selama $25 \mathrm{jam}$. Total bakteri asam 
Tabel 3. Rataan konsumsi ransum, pertambahan bobot badan, dan konversi ransum selama penelitian

\begin{tabular}{cccc}
\hline \multirow{2}{*}{ Perlakuan } & \multicolumn{3}{c}{ Parameter } \\
\cline { 2 - 4 } & $\begin{array}{c}\text { Konsumsi Ransum } \\
(\mathrm{g} / \text { ekor) }\end{array}$ & $\begin{array}{c}\text { Pertambahan Bobot Badan } \\
(\mathrm{g} / \text { /ekor })\end{array}$ & Konversi Ransum \\
\hline P0 & $2.161,68^{\mathrm{a}} \pm 21,16$ & $886,81^{\mathrm{a}} \pm 8,82$ & $2,62^{\mathrm{a}} \pm 22,77$ \\
P1 & $1.898,81^{\mathrm{a}} \pm 6,63$ & $1.044,26^{\mathrm{b}} \pm 3,70$ & $2,27^{\mathrm{ab}} \pm 13,25$ \\
P2 & $2.136,19^{\mathrm{a}} \pm 3,96$ & $1.149,64^{\mathrm{b}} \pm 9,67$ & $2,12^{\mathrm{ab}} \pm 11,14$ \\
P3 & $2.030,93^{\mathrm{a}} \pm 9,24$ & $1.128,20^{\mathrm{b}} \pm 11,02$ & $2,05^{\mathrm{b}} \pm 11,88$ \\
P4 & $1.900,17^{\mathrm{a}} \pm 6,55$ & $1.050,30^{\mathrm{b}} \pm 8,05$ & $2,18^{\mathrm{ab}} \pm 3,72$ \\
\hline
\end{tabular}

Keterangan: Huruf superscript berbeda pada kolom yang sama menunjukkan pengaruh yang berbeda sangat nyata $(\mathrm{P}<0,05)$; $\mathrm{P} 0=$ Ransum tanpa probiotik kering, $\mathrm{P} 1=$ Ransum dengan penambahan probiotik kering A (susu sapi fermentasi 100\%), P2 = Ransum dengan penambahan probiotik kering B (susu sapi fermentasi $75 \%+$ susu kacang hijau fermentasi 25\%, P3 = Ransum dengan penambahan probiotik kering $C$ (susu sapi fermentasi $75 \%+$ susu kedelai fermentasi $25 \%$ ), P4 = Ransum dengan penambahan probiotik kering D (susu sapi fermentasi $50 \%+$ susu kacang hijau fermentasi 25\% + susu kedelai fermentasi 25\%)

laktat setelah proses pengeringan berkisar 7,09 x $10^{2}$ hingga $4,51 \times 10^{3}$. Pemberian probiotik kering sebanyak $2 \%$ dari total ransum.

\section{Parameter}

Parameter yang diukur adalah performa pertumbuhan yang meliputi konsumsi ransum, pertambahan bobot badan, dan konversi ransum. Konsumsi ransum dihitung setiap hari dengan cara mengurangi jumlah ransum yang disediakan dengan sisa ransum yang tersedia. Pertambahan bobot badan dihitung setiap minggu (7 hari) berdasarkan selisih akhir minggu dengan bobot tubuh minggu sebelumnya. Konversi ransum dihitung berdasarkan jumlah ransum yang dikonsumsi selama seminggu dibagi dengan pertambahan berat tubuh pada minggu yang sama.

\section{Rancangan Percobaan dan Analisis Data}

Data di analisis dengan Rancangan Acak Lengkap (RAL) pada taraf kepercayaan $\alpha=0,05$. Penelitian ini dilakukan dengan 5 perlakuan dan 4 kali ulangan sehingga terdapat 20 unit percobaan dengan 5 ekor ayam broiler setiap unit. Adapun perlakuan dalam penelitian ini sebagai berikut:

P0 : Ransum tanpa probiotik kering

P1 : Ransum dengan penambahan probiotik kering A (susu sapi fermentasi 100\%)

P2 : Ransum dengan penambahan probiotik kering B (susu sapi fermentasi $75 \%+$ susu kacang hijau fermentasi 25\%

P3 : Ransum dengan penambahan probiotik kering C (susu sapi fermentasi $75 \%+$ susu kedelai fermentasi 25\%)

P4 : Ransum dengan penambahan probiotik kering D (susu sapi fermentasi $50 \%+$ susu kacang hijau fermentasi $25 \%+$ susu kedelai fermentasi 25\%)

Data yang diperoleh dianalisis dengan analisys of variance (ANOVA). Apabila hasil analisis ragam perlakuan adan perbedaan nyata pada taraf $5 \%$, maka analisis dilanjutkan dengan uji Duncan (Steel and Torrie, 1991).

\section{HASIL DAN PEMBAHASAN}

\section{Konsumsi Ransum}

Rataan konsumsi ransum ayam broiler yaitu berkisar 1.898,81 hingga 2.161,68 gram/ ekor (Tabel 3). Konsumsi ransum tertinggi diperoleh pada perlakuan kontrol, yaitu $2.161,68 \pm 21,16$, sedangkan terendah pada $\mathrm{P} 1$, yaitu $1.898,81 \pm 6,63$. Rataan tertinggi hingga terendah secara berurutan, yaitu P0, P2, P3, 
P1, dan P4. Hasil analisis ragam menunjukkan bahwa pemberian probiotik kering tidak menunjukkan perbedaan yang nyata $(\mathrm{P}>0,05)$ terhadap konsumsi ransum. Pengaruh tidak berbeda nyata karena pengaruh pemberian ransum yang sama dengan kandungan energi metabolis $3.066 \mathrm{kkal} / \mathrm{kg}$ dan protein 21,37\%. Rasyaf (2011) menjelaskan dua faktor yang mempengaruhi konsumsi ransum pada unggas, yaitu faktor berpengaruh dominan (kandungan energi pakan, kualitas pakan, dan suhu lingkungan) dan faktor yang berpengaruh minor (strain, bobot badan, pertumbuhan bulu, tingkat stress, dan aktifitas unggas). Pengaruh kualitas pakan berkaitan dengan imbangan energi dan protein, sehingga nutrien yang dikonsumsipun sama. Ayam broiler akan berhenti makan apabila sudah terpenuhi kebutuhan energinya.

Konsumsi ransum menurun dari tiap perlakuan masing-masing $13,85 \%(\mathrm{P} 1), 1,2 \%$ (P2), 6,44 (P3), dan 13,76\%(P4) dibandingkan perlakuan kontrol. Penurunan ini disebabkan karena adanya probiotik kering pada masingmasing perlakuan sehingga ransum yang dikonsumsi relatif rendah. Astuti et al. (2015), penambahan jumlah populasi mikroba yang menguntungkan bagi ternak akan mencegah berkembangnya mikroba patogen dalam saluran pencernaan yang berujung pada peningkatan pencernaan makanan. Persaingan antara probiotik dan bakteri patogenik sangat kompleks dan sangat kompetitif. Kondisi $\mathrm{pH}$ asam mendukung kelangsungan hidup bakteri asam laktat, seperti Lactobacilli. Lactobacilli akan berikatan dengan sel-sel epitel mukosa usus dan mengecualikan bakteri patogen seperti Salmonella spp. dan E. coli. Sel epitel yang ditumbuhi probiotik akan memengaruhi adhesi organisme di epitel mukosa dan mempengaruhi ketahanannya terhadap asam (Al-Khalaifah, 2018). Penambahan probiotik kering dapat mengefesienkan konsumsi pakan untuk diubah menjadi massa otot sehingga mempengaruhi bobot badan akhir.

Perlakuan P4 menunjukkan penurunan konsumsi dibandingkan P2 dan P3. Hal ini disebabkan tingginya kandungan isoflavon pada perlakuan tersebut. Kandungan isoflavon pada kedelai segar antara 128-380 $\mathrm{mg} / 100 \mathrm{~g}$ (Murni et al., 2013) sedangkan pada kacang hijau segar adalah 70,74 mg/100 g. Isoflavon dalam keadaan setelah fermentasi akan berubah dari glikosida menjadi aglikon dan aktivitasnya menjadi lebih meningkat. Isoflavon merupakan fitoestrogen atau estrogen yang berasal dari tumbuhan. Salah satu fungsi isoflavon adalah estrogenik yang berkaitan dengan konsumsi ransum. Weickert et al. (2006) menunjukkan bahwa estradiol atau senyawa mirip estradiol dapat berinteraksi dengan peptida YY (PYY), suatu hormon yang mempengaruhi rasa kenyang dan berakibat menurunkan nafsu makan. Estrogen dapat menyebabkan peningkatan bobot badan dan bertindak menurunkan nafsu makan. Hal ini dikarenakan adanya leptin atau protein hasil seksresi sel lemak putih yang kadarnya dipengaruhi dengan adanya estrogen, apabila meningkat makan akan mempengaruhi rendahnya konsumsi ransum. Hasil penelitian menunjukkan walaupun ransum yang dikonsumsi ayam broiler pada P4 relatif rendah tetapi pertambahan bobot badan meningkat.

\section{Pertambahan Bobot Badan}

Rataan pertambahan bobot badan ayam broiler berkisar dari 886,81 hingga 1.149,64 gram/ekor. Pertambahan bobot badan tertinggi pada perlakuan P2, yaitu 1.149,64 \pm 9,67 dan terendah pada perlakuan kontrol, yaitu 886,81 $\pm 8,82$. Hasil analisis menunjukkan bahwa perlakuan probiotik kering berbeda nyata $(\mathrm{P}<0,05)$ terhadap pertambahan bobot badan. Uji lanjut Duncan menunjukkan bahwa perlakuan P0 (kontrol) berbeda nyata dengan keempat perlakuan lainnya, sedangkan perlakuan P1, P2, P3, dan P4 tidak saling berbeda nyata. Peningkatan pertambahan bobot badan terlihat pada perlakuan yang diberikan probiotik kering. Pertambahan bobot badan meningkat dari tiap perlakuan masing-masing $15,07 \%(\mathrm{P} 1), 22,86 \%(\mathrm{P} 2)$, $21,40 \%$ (P3), dan $15,50 \%$ (P4) dibandingkan perlakuan kontrol.

Pertambahan bobot badan dipengaruhi 
oleh konsumsi ransum dan pencernaan di dalam tubuh ternak. Peningkatan efisiensi pencernaan dan penyerapan nutrisi karena adanya bakteri asam laktat. Bakteri asam laktat meningkatkan aktivitas enzim, asam lemak rantai pendek, asam laktat, serta antimikroba seperti bakteriosin, hidrogen peroksida, diasetil, dan reuterin yang efektif dapat menghambat perkembangan mikroba pathogen yang membutuhkan pH 6-7 (Murhadi et al., 2009; Astuti et al., 2015). Penurunan bakteri patogen akan meningkatkan aktivitas enzim dan memperluas permukaan vili-vili usus yang mempengaruhi peningkatkan daya cerna, penyerapan nutrisi, serta membentuk dan menambah ukuran jaringan baru (Lengkey dan Adriani, 2011; Priastoto, 2016; Adriani et al., 2019).

Pakan yang terserap dengan baik dimanfaatkan oleh ayam untuk pertumbuhan jaringan dan peningkatan berat badan (Astuti et al., 2015). Priastoto et al. (2016) penyerapan nutrien menjadi lebih baik karena vili-vili pada usus halus bertambah panjang dan densitasnya lebih padat yang menyebabkan sel goblet menjadi lebih banyak. Peningkatan jumlah dan lebar vili jejunum dari pakan yang ditambahkan probiotik yang mempengaruhi berat badan akhir ayam broiler (Adriani et al., 2019). Probiotik kering dalam ransum meningkatkan kandungan lysine analogue dan aminoethyl cysteine dalam saluran pencernaan yang diubah menjadi asam amino lisin dan sistein sehingga dapat meningkatkan retensi protein yang berperan dalam pembentukan daging (Candrasih dan Bidura, 2001). Semakin baik pencernaan dan penyerapan nutrien maka akan memberikan pertambahan bobot badan yang baik dan secara tidak langsung akan memberikan bobot badan akhir yang tinggi pula. Jin et al. (2000) melaporkan pakan ayam broiler yang ditambahkan $0,1 \%$ kultur kering Lactobacillus acidophilus atau kultur kering $0,1 \%$ kultur kering campuran 12 strain Lactobacillus menunjukkan pertambahan bobot badan meningkat secara signifikan pada kelompok yang diberi probiotik dibandingkan dengan kelompok kontrol.
Peningkatan yang tinggi terdapat pada perlakuan P2 dan P3 dengan pemberian probiotik kering yang mengandung isoflavon dari kacang hijau maupun kedelai. Isoflavon dalam bentuk glikosida akan dihidrolisis menjadi aglikon oleh enzim $\beta$-glukosidase dalam proses fermentasi, sehingga lebih mudah diserap oleh usus halus dan mempunyai mempunyai aktivitas antioksidan yang lebih baik jika dibandingkan dengan bentuk glikosida (Amadou et al., 2010). Adanya senyawa isoflavon pada probiotik kering menyebabkan metabolisme bakteri asam laktat yang mempengaruhi penyerapan nutrien dalam saluran pencernaan khususnya protein menjadi optimal dan berakibat pada tingginya protein yang tercerna. Pada metabolisme tubuh estrogen meningkatkan sintesis dan sekresi hormon pertumbuhan yang menstimulasi pertumbuhan sel dan mempercapat pertambahan bobot badan (Suprihatin, 2008). Isoflavon dengan bakteri asam laktat bersama-sama mereduksi mikroba pathogen yang menempel pada saluran pencernaan, sehingga pertambahan bobot badan meningkat karena penyerapan zat nutrisi optimal.

Pada perlakuan P4 menunjukkan penurunan dibandingkan P2 dan P3. Hal ini akibat rendahnya konsumsi ransum pada $\mathrm{P} 4$ dibandingkan P2 dan P3. Selain itu, tingginya kandungan isoflavon akumulasi dari kacang hijau dan kedelai dalam probiotik kering tersebut. Sesuai dengan temuan Muis et al. (2010) bahwa penambahan ampas susu kedelai fermentasi yang kaya isoflavon sampai $100 \%$ dalam ransum menurunkan pertambahan bobot badan ayam broiler. Isoflavon meningkatkan kadar adiponektin yang dapat menurunkan resistensi insulin dan menurunkan kadar trigliserida otot dan hati. Adiponektin adalah hormon yang mempunyai aktifitas biologis penting terhadap metabolisme glukosa, lemak dan mempengaruhi terjadinya resistensi insulin (Hariawan, 2010).

\section{Konversi Ransum}

Rataan konversi ransum ayam broiler berkisar dari 2,05 hingga 2,62. Konversi 
ransum terendah pada perlakuan $\mathrm{P} 0$, yaitu $2,62 \pm 22,77$ dan tertinggi pada P3 2,18 $\pm 3,72$. Hasil analisis ragam menunjukkan bahwa pemberian probiotik kering tidak menunjukkan perbedaan yang nyata $(\mathrm{P}>$ $0,05)$ terhadap konversi ransum. Peningkatan konversi ransum ditunjukkan oleh perlakuan yang diberikan probiotik kering. Peningkatan konversi ransum dari tiap perlakuan masingmasing 15,42\% (P1), 23,58\% (P2), 27,80\% (P3), dan 20,18\% (P4). Uji lanjut Duncan menunjukkan bahwa perlakuan P0 (kontrol) berbeda nyata dengan P3, sedangkan P1, P2, dan P4 tidak saling berbeda nyata.

Konversi ransum adalah perbandingan antara jumlah ransum yang dikonsumsi denga produksi daging yang dihasilkan dalam waktu tertentu. Sehingga konversi ransum ini dipengaruhi oleh konsumsi ransum dan pertambahan bobot badan. Semakin kecil nilai angka konversi ransum maka menunjukkan tingkat efisiensi ayam broiler memanfaatkan pakan menjadi daging.

Pemberian probiotik kering pada tiap perlakuan tidak menunjukkan perbedaan yang signifikan. Lee et al. (2010) dan Zhang et al. (2011) bahwa pemberian probiotik tidak menunjukkan hasil yang positif pada performa pertumbuhan pada ayam broiler. Probiotik meningkatkan kecernaan nutrien sehingga efesien dalam meningkatkan bobot badan tanpa meningkatkan jumlah konsumsi ransum. Jin et al. (1997) menyatakan bahwa keberadaan probiotik dalam ransum akan meningkatkan aktivitas enzimatis dan meningkatkan aktivitas pencernaan, sehingga nutrien yang biasanya banyak terbuang dalam feses akan menjadi berkurang. Konsumsi ransum biasanya dijadikan tolok ukur dalam keberhasilan pemeliharaan ayam broiler. Oleh karena itu, dengan penambahan probiotik kering dalam ransum mampu menunjukkan konversi ransum yang baik.

\section{KESIMPULAN}

Berdasarkan hasil penelitian bahwa pemberian probiotik kering menunjukkan hasil yang berbeda nyata $(\mathrm{P}<0,05)$ pada pertambahan bobot badan, sedangkan pada konsumsi ransum dan konversi ransum tidak berbeda nyata $(\mathrm{P}>0,05)$ namun terdapat perbaikan. Hal ini menunjukkan adanya pengaruh positif dari probiotik kering.

\section{UCAPAN TERIMA KASIH}

Penulis berterima kasih kepada Program Usulan Penelitian Terapan Kemenristekdikti karena telah mendanai penelitian ini dan kepada Prof. Dr. Ir. Lovita Adriani, M.Si yang telah membantu dalam menulis artikel ini.

\section{DAFTAR PUSTAKA}

Adriani, L., D. Latipudin., R. L. Balia, and T. Widjastuti. 2019. Improvement of Small Intestine Morphometry in Broiler Chicken Using Fermented Cow and Soymilk as Probiotic. International Journal of Poultry Science. 18(6): 255259.

Al-Khalaifah, H. S. 2018. Benefits of Probiotics and Prebiotics for Antibiotic Reduced Poultry. Poultry Science. 97(3): 807-815.

Amadou, I., Gbadamosi, O., Shi, Y.H., Kamara, M., Jin, S., Le C.W. 2010. Identification of Antioxidative Peptides from Lactobacillus plantaraum Lp6 Fermented Soybean Protein Meal. Research Journal of Microbiologhy. Vol. 5, No. 5, page: 372-380.

Astuti, F. K., W. Busono, dan O. Sjofjan. Pengaruh Penambahan Probiotik Cair dalam Pakan Terhadap Penampilan Produksi pada Ayam Pedaging. Jurnal Pembangunan dan Alam Lestari. 6(2).

Candrasih, N. N. K. dan I.G.N.G Bidura. 2001. Pengaruh Penggunaan Cangkang Kakao yang Disuplementasi Ragi Tape dalam Ransum Terhadap Penampilan Itik Bali.Majalah Ilmiah Peternakan. 4(3): 67-72. 
Hariawan, H. 2010. Kadar Adiponektin pada Subyek Obes dengan Mauoun Tanpa Resistensi Insulin. Jurnal Kedokteran Yarsi. 18(1): 021-028.

Hill, C., Guarner, F., Reid, G., Gibson, G. R., Merenstein, D. J. and Pot, B. 2014. The International Scientific Association for probiotics and prebiotics consensus statement on the scope and appropriate use of the termprobiotic. Nature Reviews Gastroenterology and Hepatology. 11(8): 506-514.

Jin, L. Z., Y. W. Ho., N. Abdullah, and S. Jalaludin. 1997. Probiotic in Poultry: Modes of Action. Worlds Poultry Science Journal. 53(4): 351 - 368.

Jin, L. Z., Y. W. Ho., N. Abdullah, and S. Jalaludin. 2000. Digestive and bacterial enzyme activities in broilers fed diets supplemented with Lactobacillus cultures. Poultry Science. 79: 886-891.

Kompiang, I. P. 2002. Pengaruh ragi: Saccharomyces Cerevisiae dan ragi laut sebagai Pakan Imbuhan Probiotik terhadap kinerja unggas. Jurnal Ilmu Ternak dan Veteriner. 7(1):18-21.

Lee, K. W., S. H. Lee., H. S. Lillehoj., G. X. Li., S. I. Jang, and U. S. Babu. 2010. Effects of directed microbials on growth performance, gut morphometry, and immune characteris- tics in broiler chickens. Poultry Science. 89(2): 203216.

Lengkey, H. A. W. and L. Adriani. 2011. The Effect of Lactobacillus bulgaricus and Streptococcus thermophilus as Ration Supplement on Broiler Carcass Weight, Carcass Fat Content and The Serum Cholesterol Carcass Content. International Seminar Biotechnology.

Mountzouris. K., C. P. Tsitrsikos., I. Palamidi., A.Arvaniti., M. Mohnl., G. Schatzmayr, and K. Fegeros. 2010. Effects of probiotik inclusion levels in broiler nutrion on growth performance, nutrient digestibility, plasma immunoglobulins, and cecal micrroflora compostion.
Journal Poultry Science. 89(1): 58-67.

Muis, H., Mirnawati, dan I. Martaguri. 2010. Pemanfaatan Ampas Susu Kedelai Fermentasi Sebagai Pengganti Protein Bungkil Kedelai dalam Ransum Ayam Broiler. Jurnal Embrio. 3(2): 99-97.

Murhadi., S. U. Nurdin., D. Aprizal, dan Maryanti. 2009. Pengaruh penambahan cincau pohon (Premnaoblongifolia Merr.) pada pakan terhadap kandungan bakteri asam laktat digesta dan efek laksatifnya pada tikus percobaan. Jurnal Teknolologi Industri Hasil Pertanian. 14: 129-140.

Murni, I., Reftina, E., Puji, A., Harti, A., Estuningsih, dan Kusumawati, $\mathrm{H}$. N. 2013. Pemanfaatan Bakteri Asam Laktat dalam Proses Pembuatan Tahu dan Tempe untuk Peningkatan Kadar Isoflavon, Asam Linoleat dan Asam Linolenat. Jurnal Kesehatan Kusuma Husada. 4(2): 89-95.

Priastoto, D., T. Kurtini, dan Sumardi. 2016. Pengaruh Pemberian Probiotik dari Mikroba Lokal Terhadap Performa Ayam Petelur. Jurnal Ilmiah Peternakan Terpadu. 4(1): 80-85.

Rasyaf, M. 2011. Panduan Beternak AyamPedaging. Cetakan ke-4. Penebar Swadaya, Jakarta.

Suprihatin. 2008. Optimalisasi Kinerja Reproduksi Tikus Betina Setelah Oemberian Tepung Kedelai dan Tepung Tempe Pada Usia Prapubertas (Tesis). Bogor. Sekolah Pascasarjana, Intitut Pertanian Bogor.

Triyono, A. 2010. Mempelajari Pengaruh Maltodekstrin dan Susu Skim Terhadap Karakteristik Yoghurt Kacang Hijau (Phaseolus radiatus L.). Seminar Rekayasa Kimia dan Proses. ISSN: 1411-4216.

Weickert, M. O., M. Reimann., B. Otto., W. L. Hall., K. Vafeiadou., J. Hallund., M. Ferrari., D. Talbot., F. Branca., S. Bugel., C. M. Williams., H. J. 
Zunft, and C. Koebnick. 2006. Soy Isoflavone Increase Preprandial Peptide YY (PYY), but Have No Effect on Ghrelin and Body Weight in Healthy Postmenopausal Women. Journal Negat Results Biomed. 5(11).
Zhang, B. K., X. Yang., Y. M. Guo, and F. Y. Long. 2011. Effects od dietary lipids and Clostridium butyricum on the performance and the digestive tract of broiler chickens. Archives of Animal Nutrition. 65(4): 329-339. 